\title{
Oral hyaluronan relieves knee pain: a review
}

\author{
Mariko Oe ${ }^{1}\left(\mathbb{D}\right.$, Toshiyuki Tashiro$^{2}$, Hideto Yoshida ${ }^{1}$, Hiroshi Nishiyama', Yasunobu Masuda ${ }^{1 *}$, Koh Maruyama $^{3}$, \\ Takashi Koikeda ${ }^{4}$, Reiko Maruya ${ }^{5}$ and Naoshi Fukui ${ }^{6}$
}

\begin{abstract}
Hyaluronan (HA) is a component that is particularly abundant in the synovial fluid. Randomized, double-blinded, placebo-controlled trials carried out between 2008 and 2015 have proven the effectiveness of HA for the treatment of symptoms associated with synovitis, and particularly, knee pain, relief of synovial effusion or inflammation, and improvement of muscular knee strength. The mechanism by which HA exerts its effects in the living body, specifically receptor binding in the intestinal epithelia, has gradually been clarified. This review examines the effects of HA upon knee pain as assessed in clinical trials, as well as the mechanism of these effects and the safety of HA.
\end{abstract}

Keywords: Hyaluronan, Hyaluronic acid, Dietary supplement, Knee, Joint, Osteoarthritis

\section{Introduction}

The number of patients with osteoarthritis $(\mathrm{OA})$ is increasing in developed countries. In the US, 43 million patients were estimated to have OA in 1997, and this figure is projected to grow to more than 60 million by 2020 [1].

Severe OA is treated by osteotomy or artificial joint replacement, whereas conservative treatments include intra-articular injection of hyaluronan (HA) [2]. The injections improve symptoms, although they represent a mental burden and the risk of infection for patients who need to visit the hospital regularly to receive these painful injections.

Meanwhile, dietary supplements such us HA, glucosamine, and chondroitin are sold as health foods, largely targeting problems with the knee. The effects of lowdose HA treatment for knee pain has been the source of much research (for example, a dose of HA not more than $240 \mathrm{mg} /$ day; Table 1) compared with glucosamine (1500 mg/day) and chondroitin (675 mg/day) [3]. HA dietary supplements impose a small burden on patients.

The average wholesale price for five vials of intraarticular HA injection (Hyalgen ${ }^{\circ}$, Fidia Farmaceutici S.p.A., Italy) is 661 USD, which is effective for 6 months

\footnotetext{
*Correspondence: yasunobu_masuda@kewpie.co.jp ${ }^{1}$ R\&D Division, Kewpie Corporation, 2-5-7, Sengawa-cho, Chofu-shi, Tokyo, Japan

Full list of author information is available at the end of the article
}

[4]. This equals to 110 USD per month. In contrast, the cost of effective HA dietary supplements for one month is 50 USD (Play Again Now ${ }^{\circ}$, Viscos LLC., USA). There have been no reports regarding the cost-effectiveness of intra-articular injection versus dietary supplements. However, there are some advantages for consumers with regard to HA dietary supplements, when one considers the potential risks and benefits.

In 2004, Bucci and Turpin reported a review article on the effectiveness of dietary supplements containing HA in the US; however, the report does not mention randomized, double-blind, placebo-controlled trials [5]. Therefore, this review discusses the efficacy of ingested HA in treating knee pain based on data from randomized, double-blind, placebo-controlled trials as well as the mechanism of action and safety of dietary HA.

\section{Characteristics of HA}

HA is a high molecular-weight polysaccharide composed of repeating polymeric disaccharides of D-glucuronic acid and $N$-acetyl-D-glucosamine (Fig. 1) [6]. All vertebrates and few microorganisms synthesize HA in vivo. In human beings, HA is present in every connective tissue and organ such as skin, synovial fluid, blood vessels, serum, brain, cartilage, heart valves, and the umbilical cord [7]. In particular, synovial fluid has the highest concentration of HA anywhere in the body at $3-4 \mathrm{mg} / \mathrm{mL}$ [8]. 
Table 1 Summary of the knee pain-improving effects of ingested hyaluronan

\begin{tabular}{|c|c|c|c|c|}
\hline Study designs & Materials and Methods & Subjects & Results & References \\
\hline $\begin{array}{l}\text { Randomized, double-blind, } \\
\text { placebo-controlled trial }\end{array}$ & $\begin{array}{l}\text { HA mixture at } 630 \mathrm{mg} \text { (HA } 60 \mathrm{mg} \text {; MW } \\
<5 \text { k) daily for } 2 \text { weeks }\end{array}$ & $\begin{array}{l}24 \text { patients with } \\
\text { knee pain (in Japan) }\end{array}$ & $\begin{array}{l}\text { Significant improve of knee pain } \\
\text { and discomfort }\end{array}$ & [34] \\
\hline $\begin{array}{l}\text { Randomized, double-blind, } \\
\text { placebo-controlled trial }\end{array}$ & $\begin{array}{l}\text { HA mixture at } 80 \text { mg (HA } 48 \text { mg; MW } \\
1000 \text { k) daily for } 2 \text { months }\end{array}$ & $\begin{array}{l}20 \text { patients aged } \\
\geq 40 \text { years with knee } \\
\text { OA (in USA) }\end{array}$ & $\begin{array}{l}\text { Significant improve from baseline } \\
\text { for bodily pain bodily pain subscale } \\
\text { and physical component summary. }\end{array}$ & [35] \\
\hline $\begin{array}{l}\text { Randomized, double-blind, } \\
\text { placebo-controlled trial }\end{array}$ & $\begin{array}{l}\mathrm{HA} \text { at } 240 \mathrm{mg} \text { (MW } 900 \mathrm{k} \text { ) daily for } \\
8 \text { weeks }\end{array}$ & $\begin{array}{l}26 \text { patients aged } 50 \\
\sim 65 \text { years with knee } \\
\text { pain (in Japan) }\end{array}$ & $\begin{array}{l}\text { Significant improve of knee pain } \\
\text { and stiffness }\end{array}$ & [36] \\
\hline $\begin{array}{l}\text { Randomized, double-blind, } \\
\text { placebo-controlled trial }\end{array}$ & $\begin{array}{l}\text { HA at } 200 \mathrm{mg} \text { (MW } 900 \mathrm{k} \text { ) daily for } \\
8 \text { weeks }\end{array}$ & $\begin{array}{l}25 \text { patients with } \\
\text { knee OA [WOMAC } \\
\text { pain score }>10 \text { ] (in } \\
\text { USA) }\end{array}$ & $\begin{array}{l}\text { Significant improve of tatal WOMAC } \\
\text { score and activity of daily living }\end{array}$ & [37] \\
\hline $\begin{array}{l}\text { Retrospective cohort study, } \\
\text { PCT-controlled trial }\end{array}$ & $\begin{array}{l}\text { HA mixture at } 80 \mathrm{mg} \text { (HA } 48 \text { mg; MW N/ } \\
\text { A) daily for } 6 \text { months }\end{array}$ & $\begin{array}{l}69 \text { patients with } \\
\text { knee OA and } \\
\text { synovitis (in Spain) }\end{array}$ & $\begin{array}{l}\text { Significant improve of synovial } \\
\text { effusion and knee pain }\end{array}$ & [38] \\
\hline $\begin{array}{l}\text { Randomized, double-blind, } \\
\text { placebo-controlled trial }\end{array}$ & $\begin{array}{l}\text { HA mixture at } 630 \text { mg (HA } 60 \text { mg; MW } \\
<5 \text { k) daily for } 4 \text { months }\end{array}$ & $\begin{array}{l}40 \text { patients with } \\
\text { knee OA and } \\
\text { synovitis (in Japan) }\end{array}$ & $\begin{array}{l}\text { Significant improve of pain/step-up } \\
\text { and -down function and aggregate } \\
\text { total symptoms }\end{array}$ & [39] \\
\hline $\begin{array}{l}\text { Randomized, double-blind, } \\
\text { placebo-controlled trial }\end{array}$ & $\begin{array}{l}\text { HA mixture at } 2520 \mathrm{mg} \text { (HA } 72 \text { mg; MW } \\
<5 \text { k) daily for } 12 \text { weeks }\end{array}$ & $\begin{array}{l}29 \text { patients with } \\
\text { knee OA and } \\
\text { synovitis (in Japan) }\end{array}$ & $\begin{array}{l}\text { Significant improve of bone } \\
\text { metabolism marker }\end{array}$ & [40] \\
\hline \multirow[t]{2}{*}{$\begin{array}{l}\text { Randomized, double-blind, } \\
\text { placebo-controlled trial }\end{array}$} & \multirow[t]{2}{*}{$\begin{array}{l}\text { HA at } 200 \mathrm{mg} \text { (MW } 900 \mathrm{k} \text { ) daily for } \\
12 \text { months }\end{array}$} & $\begin{array}{l}38 \text { patients with } \\
\text { knee OA (in Japan) }\end{array}$ & $\begin{array}{l}\text { Significant improve of Health } \\
\text { condition }\end{array}$ & \multirow[t]{2}{*}{ [41] } \\
\hline & & $\begin{array}{l}21 \text { patients aged } \\
\leqq 70 \text { years with knee } \\
\text { OA (in Japan) }\end{array}$ & $\begin{array}{l}\text { Significant improve of total JKOM } \\
\text { score, pain and stiffness in the knee } \\
\text { and general activities }\end{array}$ & \\
\hline $\begin{array}{l}\text { Randomized, double-blind, } \\
\text { placebo-controlled trial }\end{array}$ & $\begin{array}{l}\text { HA mixture at } 80 \text { mg (HA } 52 \text { mg; MW N/ } \\
\text { A) daily for } 90 \text { days }\end{array}$ & $\begin{array}{l}40 \text { healthy } \\
\text { individuals with mild } \\
\text { joint discomfort (in } \\
\text { Spain) }\end{array}$ & $\begin{array}{l}\text { Significant improve of joint } \\
\text { mechanics and muscle function }\end{array}$ & [42] \\
\hline $\begin{array}{l}\text { Meta-analysis included in two } \\
\text { randomized, controlled, double- } \\
\text { blind, placebo-controlled trials }\end{array}$ & $\begin{array}{l}\text { HA mixture at } 80 \mathrm{mg} \text { (HA } 48 \text { mg; MW N/ } \\
\text { A) daily for } 3 \text { months }\end{array}$ & $\begin{array}{l}148 \text { healthy } \\
\text { individuals with mild } \\
\text { knee pain (in Spain) }\end{array}$ & $\begin{array}{l}\text { Significant improve of muscle } \\
\text { function, synovial effusion and } \\
\text { reduces pain }\end{array}$ & [43] \\
\hline $\begin{array}{l}\text { Randomized, double-blind, } \\
\text { placebo-controlled trial }\end{array}$ & $\begin{array}{l}\text { HA mixture at } 80 \mathrm{mg} \text { (HA } 52 \text { mg; MW N/ } \\
\text { A) daily for } 90 \text { days }\end{array}$ & $\begin{array}{l}68 \text { healthy } \\
\text { individuals with mild } \\
\text { joint discomfort (in } \\
\text { Spain) }\end{array}$ & $\begin{array}{l}\text { Significant improve of articular pain, } \\
\text { synovial effusion and knee muscular } \\
\text { strength }\end{array}$ & [44] \\
\hline $\begin{array}{l}\text { Randomized, double-blind, } \\
\text { placebo-controlled trial }\end{array}$ & $\begin{array}{l}\text { HA mixture at } 80 \mathrm{mg} \text { (HA } 56 \text { mg; MW N/ } \\
\text { A) daily for } 3 \text { months }\end{array}$ & $\begin{array}{l}40 \text { patients with } \\
\text { knee OA (in USA) }\end{array}$ & $\begin{array}{l}\text { Significant improve of total WOMAC } \\
\text { score and knee pain }\end{array}$ & [45] \\
\hline $\begin{array}{l}\text { Randomized, double-blind, } \\
\text { placebo-controlled trial }\end{array}$ & $\begin{array}{l}\text { HA mixture daily for } 4 \text { weeks (HA } 225 \text { mg } \\
\text { daily for first } 2 \text { weeks, HA } 150 \text { mg daily } \\
\text { for last } 2 \text { weeks; MW } 2500 \text { k } 2800 \text { k) }\end{array}$ & $\begin{array}{l}72 \text { patients with } \\
\text { knee pain (in USA) }\end{array}$ & Significant improve of knee pain & [46] \\
\hline
\end{tabular}

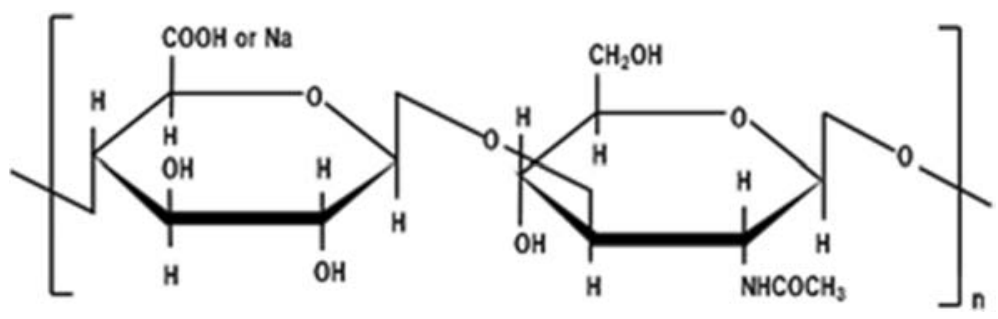

Fig. 1 The structure of hyaluronan 
HA is a polysaccharide with a mean molecular weight $(\mathrm{MW})$ ranging from several hundred to several millions, and thus, it has high viscosity in water. The viscosity of synovial fluid is attributable to HA and serves as a lubricant for joint movements, resulting in a coefficient of friction of nearly zero in joint cartilage [9]. It is known that patients with OA have diminished HA concentrations in their synovial fluid [10]. To restore the decreased levels of HA and treat OA, HA intra-articular injections are widely used. The functions of HA include preventing cartilage denaturation $[11,12]$, protecting the outer layer of cartilage [13-20], blocking synovial inflammation [21, 22], increasing chondrocyte density [23], promoting synovium metabolism [24], normalizing synovial fluid [25], and treating sharp pain [26]. The mechanism by which HA diminishes pain has been reported. HA intra-articular injections decrease the levels of inflammatory substances such as prostaglandin E2 resulting in reduced pain $[27,28]$. Therefore, $\mathrm{HA}$ is known to have a strong relationship with knee joint health.

\section{Mechanisms of oral HA treatment for knee pain}

It is generally believed that it is difficult for the body to absorb a polysaccharide. HA is not absorbed into the body as a high-molecular-weight polymer after ingestion. A test using intestinal epithelia model cells (Caco-2 cells) revealed that HA with a MW exceeding $1 \times 10^{5}$ is rarely absorbed. On the contrary, the amount of HA absorbed by Caco- 2 cells increases as the MW of HA decreases to $7 \times 10^{4}, 2 \times 10^{4}$, or $5 \times 10^{3}$ [29]. Kurihara et al. reported that HA is decomposed into 2-6-membered polysaccharides by enteric bacteria, and these polysaccharides are partially absorbed into the body by the small intestine [30]. Following the decomposition of HA by enteric bacteria to a low MW form, free polysaccharides are known to migrate into the joints and other tissues. Lactobacillus and Bzfidobacterirn have been reported as examples of enteric bacteria that play a critical role in HA absorption [31]. Balogh et al. reported

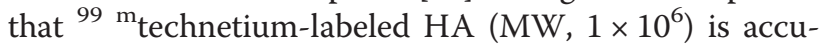
mulated by tissues such as joints after oral administration in rats and dogs [32]. The pattern of tissue uptake of radioactivity for ${ }^{99} \mathrm{~m}$ technetium-labeled HA did not resemble that for ${ }^{99 \mathrm{~m}}$ technetium-labeled pertechnetate (PCT), which was used as a control; this implies that ${ }^{99 \mathrm{~m}}$ technetium-labeled HA did not release ${ }^{99 \mathrm{~m}}$ technetium in tissues.

These studies clearly suggest that HA is absorbed by the body; however further research is needed to clarify the effects of the route of absorption on knee pain relief.

Another mechanism was clarified by Asari et al. in 2010 [33]. This report identified a signaling cascade in which receptors on intestinal epithelial cells are activated by oral HA which results in decreased pain. HA (MW, $9 \times 105$; Hyabest $^{\circ}(\mathrm{J})$, Kewpie Corporation, Tokyo, Japan) was administered orally to MRL-lpr/lpr mice, a Th-1type autoimmune disease model. Oral HA binds to an intestinal receptor (Toll-like receptor-4;TLR-4). Cytokine array analysis showed that HA enhanced the production of interleukin-10 (IL-10), an anti-inflammatory cytokine. DNA array analysis of tissue from the large intestine showed that HA up-regulates suppressor of cytokine signaling 3 (SOCS3) expression and down-regulates pleiotrophin expression. These results suggest that the binding of HA to TLR-4 promotes IL-10 and SOCS3 expression and suppresses pleiotrophin expression leading to anti-inflammation of arthritis (Fig. 2).

\section{Clinical trials of oral HA for the treatment of knee pain}

We searched the databases up to October 29, 2015; PubMed, the Cochrane Library, Scopus, UMIN-CTR, JDreamIII (in Japanese), and Ichushi Web (in Japanese). The search words used for all databases contained the terms; hyaluronan, intake and knee pain. We selected following 13 relevant reports after full text review [31-43].

Many randomized, double-blind, placebo-controlled trials have demonstrated the effectiveness of dietary HA in alleviating knee pain since 2008 in the US, EU, and Asia (Table 1).

In 2008, a dietary supplement containing HA as the principal ingredient was reported following two clinical trials. As the supplement contains multiple components, the potential effects of ingredients other than $\mathrm{HA}$ on knee pain cannot be denied but the effects of the supplement on knee pain were confirmed.

Hatayama et al. [34] treated 24 Japanese patients with chronic knee pain (HA group, $n=13$; placebo group, $n$ $=11$, mean age, 47.5) with an HA mixture at a dose of $1800 \mathrm{mg} /$ day (HA content, $60 \mathrm{mg} /$ day) or placebo for 2 weeks. The HA group displayed a significant improvement in knee pain and discomfort compared with the placebo group $(p<0.05)$.

In the US, Kalman et al. [35] treated 20 subjects aged $\geq 40$ years with knee OA (HA group, $n=11$; placebo group, $n=9$, mean age, 56.3) with an HA mixture at a dose of $80 \mathrm{mg} /$ day (HA content, $48 \mathrm{mg} /$ day) or placebo for 2 months and their outcomes were evaluated using the index for knee joint pain; the Western Ontario and McMaster Universities Osteoarthritis Index (WOMAC), and the Short Form-36 Acute US Version 2 (SF-36v2) as a quality of life (QOL) index. [REMARK 4] The WOMAC score in both groups revealed significant improvements in knee pain compared with baseline $(p<$ 0.05 ) but the physical function and total symptom scores of the HA group displayed a more drastic improvement than those of the placebo group. On the SF-36 v2, the 


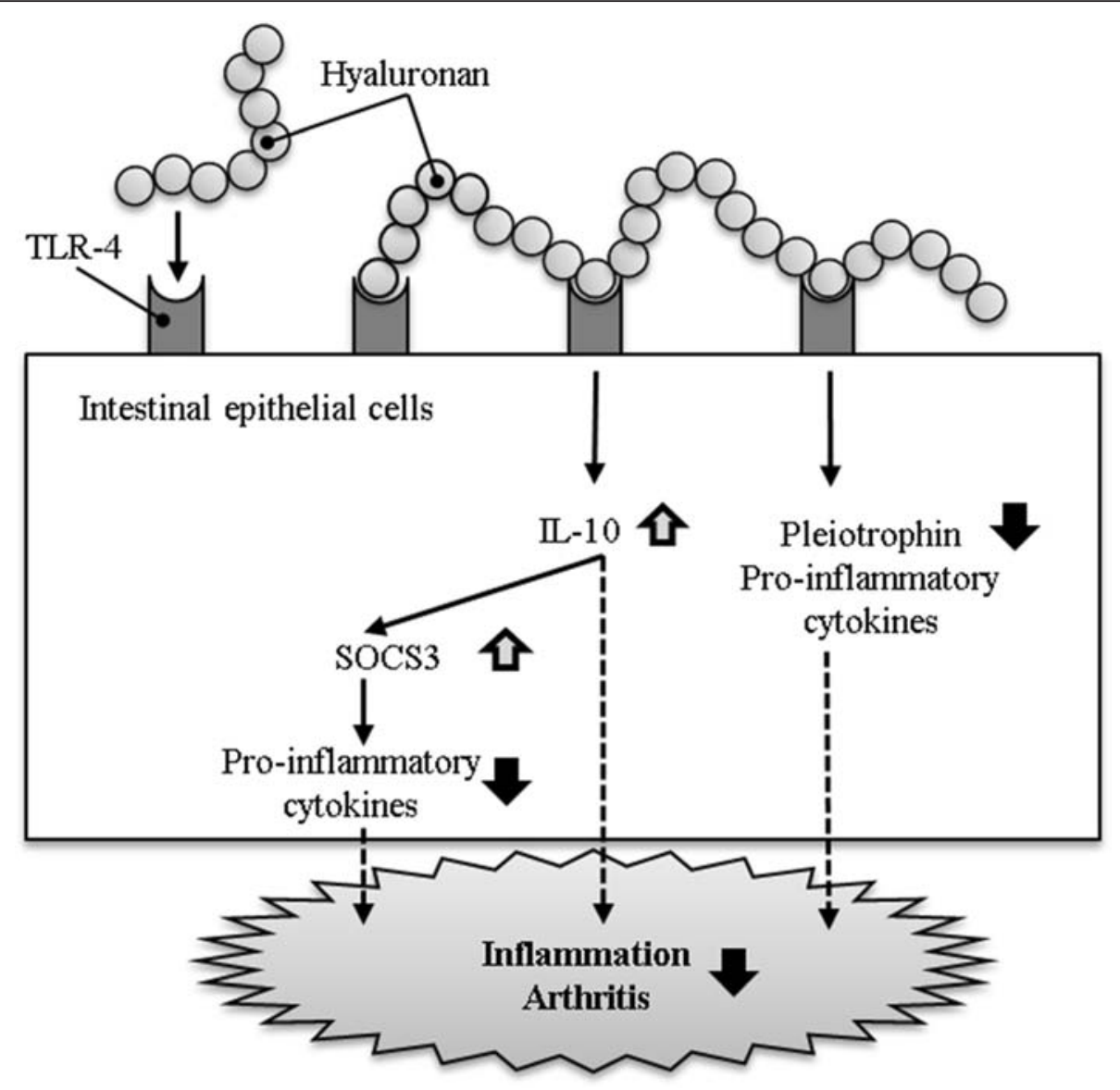

Fig. 2 Mechanism of improve the arthritis. Oral administration of hyaluronan modulates inflammation by upregulating suppressor of cytokine signaling-3 expression and down-regulating pleiotrophin expression via Toll-like receptor-4 in intestinal epithelial cells

scores of the HA group were significantly improved versus baseline $(p<0.05)$ for bodily pain and the physical component summary, and the scores were more significantly improved in the HA group than in the placebo group.

In 2009, two clinical trials using highly pure HA (more than $98 \%$ pure) were reported. These trials revealed that the effects of HA-containing supplements on knee pain were attributable to $\mathrm{HA}$.

Iwaso et al. [36] reported that 33 Japanese patients with knee pain (HA group, $n=16$; placebo group, $n=17$, mean age, 58.3) were administered HA at $240 \mathrm{mg} /$ day or placebo for 8 weeks and outcomes were evaluated using the Japanese Knee Osteoarthritis Measure (JKOM). The JKOM score was significantly improved compared with baseline in both groups $(p<0.01)$, particularly among 26 patients aged $50-65$ years (HA group, $n=13$; placebo group, $n=13)$. Significant improvements in knee pain and stiffness were recorded in the HA group compared with the placebo group $(p<0.05)$.

Sato et al. [37] reported a study in which 37 Americans with knee OA (HA group, $n=20$; placebo group, $n$
$=17$, mean age, 70.8) were orally administered $200 \mathrm{mg} /$ day HA or placebo for 8 weeks with the findings illustrating that the WOMAC score was significantly improved in both groups versus baseline $(p<0.05)$, particularly among the 25 patients with WOMAC pain scores of more than 10 (HA group, $n=13$; placebo group, $n=12$ ). In addition, the WOMAC total score and activity of daily living score were significantly improved in the HA group compared with the placebo group $(p<0.05)$.

In the same year, Möller et al. [38] conducted a retrospective cohort study in Spain in which HA was compared with the analgesic drug paracetamol (PCT). Sixty-nine patients (mean age, N/A) with knee OA and synovitis were administered an HA mixture at $80 \mathrm{mg} /$ day (HA content, $48 \mathrm{mg} /$ day) or PCT for 6 months. Ultrasonography showed that the course of synovitis in the suprapatellar recess was significantly reduced in the HA group compared with the PCT group $(p<0.0001)$, and the number of severe synovial effusion cases were significantly reduced in the HA group compared with the PCT group $(p<0.001)$. 
Between 2010 and 2015, eight clinical trials were reported indicating that interest in HA intake was becoming more intense in developed nations.

In 2010, Nagaoka et al. [39] reported that 40 Japanese patients with knee OA (HA group, $n=19$; placebo group, $n=21$, mean age, 62.9) were administered an oral HA mixture at $1800 \mathrm{mg} /$ day (HA content, $60 \mathrm{mg} /$ day) or placebo for 4 months and the result illustrated that pain/step-up and step-down function and the aggregate total symptoms of the Japanese Orthopaedic Association clinical trials response criteria were significantly improved in the HA group compared with the placebo group $(p<0.05)$ indicating relief of knee pain.

In 2012, Yoshimura et al. [40] reported that 29 Japanese athletes (HA group, $n=14$; placebo group, $n=15$, mean age, 20.0) were administered an HA mixture at $4800 \mathrm{mg} /$ day (HA content, $72 \mathrm{mg} /$ day) or placebo for 12 weeks. The urine levels of the bone metabolic markers $\mathrm{N}$-terminal telopeptides of bone-specific type I collagen were significantly lower in the HA group $(p<$ $0.05)$. This result indicates that oral HA influences knee joint health.

Tashiro et al. [41] reported a study in which 38 Japanese patients with knee OA (HA group, $n=18$; placebo group, $n=20$, mean age, 69.9) were administered highly pure HA (more than $97 \%$ ) at $200 \mathrm{mg} /$ day or placebo for 12 months. During the trial, the patients were requested to conduct quadriceps-strengthening exercise daily as part of the treatment. The result reveals that quality of life according to the JKOM score was significantly improved in the HA group versus the placebo group $(p<$ 0.05 ) and this trend was more obvious among patients aged $\leq 70$ years $(n=21)$. For these relatively younger patients in the HA group, the total JKOM score was significantly better than that in the placebo group $(p<$ $0.05)$. Thus, HA intake and quadriceps-strengthening exercise affectively alleviate knee pain particularly in patients aged $\leq 70$ years (Fig. 3).

In 2013, Martinez-Puig et al. [42] reported that 50 healthy subjects with joint discomfort (VAS between 10 and $40 \mathrm{~mm}$; HA group, $n=20$; placebo group, $n=20$, mean age, 59.6) were administered an HA mixture at $80 \mathrm{mg} /$ day (HA content, $48 \mathrm{mg} /$ day) or placebo for 90 days and outcomes were evaluated using an isokinetic dynamometer. Maximum peak torque was significantly greater in the HA group than in the placebo group $(p<$ $0.05)$. In the HA group, the total knee extension and mean power of knee extension were also significantly higher than the values in the placebo group $(p<0.05)$. This trial demonstrated that oral HA effectively improves the ability of the knee joint to bend and stretch.

Moriña et al. [43] reported a meta-analysis of two randomized, controlled, double-blind, placebo-controlled trials involving a total of 148 patients with mild knee

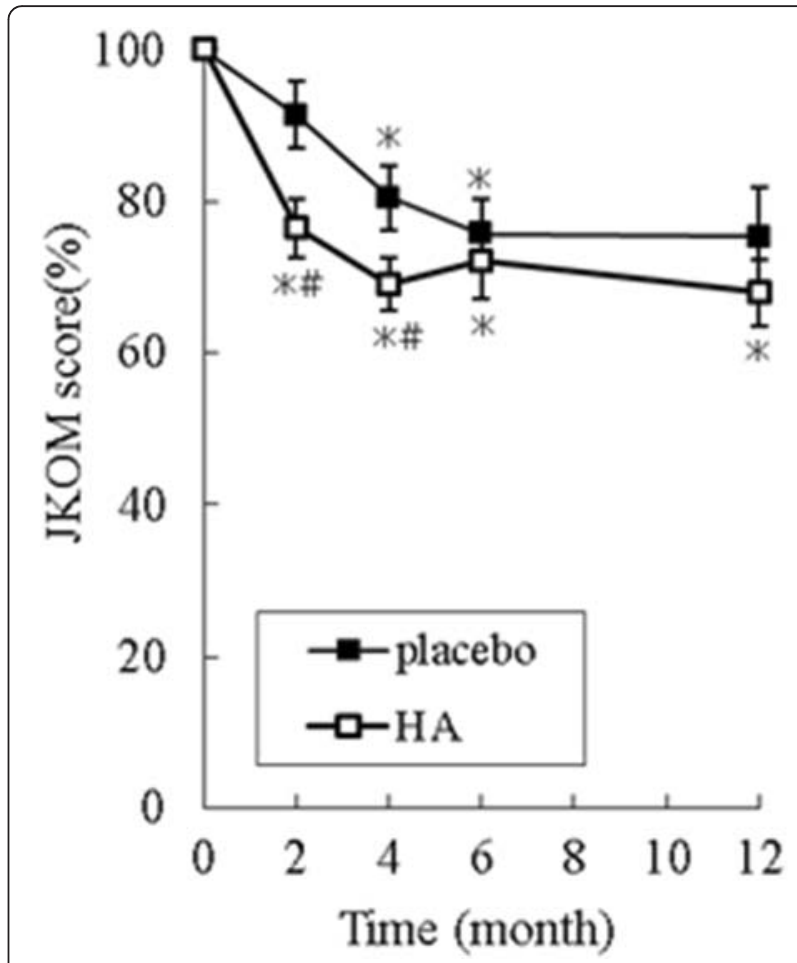

Fig. 3 Oral hyaluronan improve knee osteoarthritis: a randomized, double-blind, placebo-controlled trial. Twenty-one subjects ( $\leq 70$ years of age) were randomly divided into two groups (hyaluronan group, $n$ $=11$; placebo group, $n=10$ ). Variations in the total Japanese Knee Osteoarthritis Measure score relative to baseline are shown. $\square$ hyaluronan; placebo. Values are presented as the mean \pm SE. $p<0.05$ vs. baseline; $\# p<0.05$ vs. placebo group

pain (VAS between 30 and $50 \mathrm{~mm}$, aged from 20 to 75 ). In the studies, patients were administered an oral HA mixture at $80 \mathrm{mg} /$ day (HA content, $48 \mathrm{mg} /$ day) or placebo for 3 months and outcomes were evaluated using an isokinetic dynamometer. The analysis indicated that the affected joint displayed greater flexion in the HA group than in the placebo group $(p=0.039)$. The result of ultrasound examination for synovial effusion illustrated that synovial effusion was significantly reduced in the HA group $(p=0.029)$. An evaluation using a VAS indicated that knee pain was additionally improved in the HA group compared with the findings in the placebo group $(p=0.0036)$.

In 2014, Sánchez et al. [44] reported that 68 patients with mild knee pain (VAS between 30 and $50 \mathrm{~mm}$; HA group, $n=34$; placebo group, $n=34$, mean age, 69.5) were administered an oral HA mixture at $80 \mathrm{mg} /$ day (HA content, $48 \mathrm{mg} /$ day) or placebo for 90 days. A significant improvement in knee pain according to the VAS was recorded in the HA group compared with the placebo group $(p=0.0005)$. An ultrasound examination indicated that synovial effusion was reduced in the HA group $(p=0.041)$. The result using an isokinetic 
Table 2 Safety tests of hyaluronan

\begin{tabular}{|c|c|c|c|c|c|}
\hline \multicolumn{2}{|c|}{ Test procedures } & Subjects & Route & Results & References \\
\hline \multirow{9}{*}{\multicolumn{2}{|c|}{$\begin{array}{l}\text { Randmized, double-blind, } \\
\text { placebo-controlled trial }\end{array}$}} & Human & Oral administration, 60 mg/day for 2 weeks & $\begin{array}{l}\text { No adverse event } \\
\text { related to hyaluronan. }\end{array}$ & [34] \\
\hline & & Human & Oral administration, 48 mg/day for 2 months & $\begin{array}{l}\text { No adverse event } \\
\text { related to hyaluronan. }\end{array}$ & [35] \\
\hline & & Human & Oral administration, 240 mg/day for 8 weeks & $\begin{array}{l}\text { No adverse event } \\
\text { related to hyaluronan. }\end{array}$ & [36] \\
\hline & & Human & Oral administration, 200 mg/day for 8 weeks & $\begin{array}{l}\text { No adverse event } \\
\text { related to hyaluronan. }\end{array}$ & [37] \\
\hline & & Human & Oral administration, 60 mg/day for 4 months & $\begin{array}{l}\text { No adverse event } \\
\text { related to hyaluronan. }\end{array}$ & [39] \\
\hline & & Human & Oral administration, 200 mg/day for 12 months & $\begin{array}{l}\text { No adverse event } \\
\text { related to hyaluronan. }\end{array}$ & [41] \\
\hline & & Human & Oral administration, 52 mg/day for 3 months & $\begin{array}{l}\text { No adverse event } \\
\text { related to hyaluronan. }\end{array}$ & [42] \\
\hline & & Human & Oral administration, 52 mg/day for 3 months & $\begin{array}{l}\text { No adverse event } \\
\text { related to hyaluronan. }\end{array}$ & [43] \\
\hline & & Human & $\begin{array}{l}\text { Oral administration for } 4 \text { weeks ( } 225 \mathrm{mg} / \text { day for first } \\
2 \text { weeks, } 150 \mathrm{mg} / \text { day for last } 2 \text { weeks) }\end{array}$ & $\begin{array}{l}\text { No adverse event } \\
\text { related to hyaluronan. }\end{array}$ & [46] \\
\hline \multirow{5}{*}{\multicolumn{2}{|c|}{ single-dose toxicity study }} & Mouse & Oral administration & LD50 $(\mathrm{mg} / \mathrm{kg})>2400$ & [48] \\
\hline & & Mouse & Oral administration & LD50 (mg/kg) > 500 & [49] \\
\hline & & Rat & Oral administration & LD50 $(\mathrm{mg} / \mathrm{kg})>800$ & [48] \\
\hline & & Rat & Oral administration & LD50 $(\mathrm{mg} / \mathrm{kg})>200$ & [50] \\
\hline & & Rabbit & Oral administration & LD50 $(\mathrm{mg} / \mathrm{kg})>1000$ & [48] \\
\hline \multirow{11}{*}{\multicolumn{2}{|c|}{ Repeated-dose toxicity study }} & Rat & $\begin{array}{l}\text { Subcutaneous administration for } 13 \text { weeks with } 4 \text { weeks } \\
\text { recovery test }\end{array}$ & NOAEL 50 mg/kg/day & [51] \\
\hline & & Beagle dog & $\begin{array}{l}\text { Subcutaneous administration for } 13 \text { weeks with } 4 \text { weeks } \\
\text { recovery test }\end{array}$ & NOAEL 10 mg/kg/day & {$[52]$} \\
\hline & & Rat & Oral administration for 30 days & NOAEL 1500 mg/kg/day & {$[53]$} \\
\hline & & Rat & Oral administration for 90 days & NOAEL 1333 mg/kg/day & {$[54]$} \\
\hline & & Rat & Oral administration for 90 days & NOAEL 1000 mg/kg/day & {$[55]$} \\
\hline & & Rat & Oral administration 28 days & NOAEL 3500 mg/kg/day & {$[56]$} \\
\hline & & Rat & Intraperitoneal administration 90 days & NOAEL 9 mg/kg/day & [57] \\
\hline & & Rat & Intraperitoneal administration for 3 months & NOAEL 60 mg/kg/day & [58] \\
\hline & & Rat & Oral administration for 13 weeks & NOAEL 12.5 mg/kg/day & [59] \\
\hline & & Rat & Oral administration for 90 days with 28 days recovery test & NOAEL 48 mg/kg/day & [60] \\
\hline & & Beagle dog & Intra-articular administration for 6 months & NOAEL 12 mg/kg/day & [61] \\
\hline \multirow{4}{*}{\multicolumn{2}{|c|}{$\begin{array}{l}\text { Reproductive and developmental } \\
\text { toxicity studies }\end{array}$}} & Rat & Subcutaneous administration & NOAEL 50 mg/kg/day & [62-64] \\
\hline & & Rat & Oral administration & NOAEL 670 mg/kg/day & [65] \\
\hline & & Rat & Subcutaneous administration & NOAEL 50 mg/kg/day & [66-68] \\
\hline & & Rabbit & Subcutaneous administration & NOAEL 50 mg/kg/day & [69] \\
\hline \multirow[t]{5}{*}{$\begin{array}{l}\text { Mutagenicity } \\
\text { test }\end{array}$} & $\begin{array}{l}\text { Reverse mutation } \\
\text { test }\end{array}$ & $\begin{array}{l}\text { Bacteria(Ames } \\
\text { test) }\end{array}$ & 1000 Mg/plate & Negative & [70] \\
\hline & $\begin{array}{l}\text { Chromosomal } \\
\text { aberration test }\end{array}$ & $\begin{array}{l}\text { Mammalian } \\
\text { cultured cell }\end{array}$ & $1.00 \mathrm{mg} / \mathrm{mL}$ & Negative & [71] \\
\hline & & $\begin{array}{l}\text { Mammalian } \\
\text { cultured cell }\end{array}$ & 1000 mg/plate & Negative & [72] \\
\hline & Micronucleus test & Mouse & 300 mg/kg & Negative & [73] \\
\hline & & Mouse & Intraperitoneal administration, 30 mg/kg & Negative & [74] \\
\hline \multicolumn{2}{|c|}{ Antigenicity study } & Mouse, Rat & Intraperitoneal administration, 100 mg/個体 & Negative & [75] \\
\hline
\end{tabular}


Table 2 Safety tests of hyaluronan (Continued)

\begin{tabular}{llll}
\hline & Guinea pig & & Negative \\
& Rabbit & Intramuscularl administration, 30 mg/kg & Negative \\
Influence on cancer cell & Mouse, cell & Oral administration, $200 \mathrm{mg} /$ day & $\begin{array}{l}\text { No influence on cancer } \\
\text { cell }\end{array}$ \\
\hline
\end{tabular}

dynamometer illustrated that muscular strength (peak torque) was significantly greater among patients in the HA group than among those in the placebo group ( $p=$ 0.0324 ). Blood tests for RNA expression were conducted in 20 patients (HA group, $n=10$; placebo group, $n=10$ ). The results demonstrated that the expression of genes related to glycosaminoglycan metabolism and extracellular matrix dynamics differed between the HA and placebo groups. It was concluded that differences in gene expression explained the improvements in knee pain and muscular strength in the HA group.

In 2015, Nelson et al. [45] treated 40 patients with knee OA (VAS $>50 \mathrm{~mm}$; HA group, $n=21$; placebo group, $n=19$, mean age, 61.0) with an oral HA mixture at $80 \mathrm{mg} /$ day (HA content, $56 \mathrm{mg} /$ day) or placebo for 3 months. Significant improvements in the VAS, WOMAC total score, and WOMAC pain score were observed in the HA group compared with the placebo group $(p<0.05)$. An analysis of serum and synovial fluid illustrated that inflammatory cytokine levels were significantly increased in the placebo group $(p<0.05)$ and significantly decreased in the HA group $(p<0.05)$. Regarding bradykinin, which related to inflammation and pain, and leptin, which is related to OA caused by obesity, the levels of both substances were significantly lower in the HA group than in the placebo group $(p<$ $0.05)$. Ten patients in each group drank large amounts of water to examine the turnover of HA in synovial fluid. The turnover rate was significantly decreased in the HA group compared with that in the placebo group $(p=$ 0.046). Consequently, this report demonstrated that the oral intake of $\mathrm{HA}$ is useful for treating obese patients with OA.

In 2015, Jensen et al. [46] conducted a study in which 72 patients with knee OA (HA group, $n=37$; placebo group, $n=35$, mean age, 47.2) were administered a liquid HA mixture or placebo for 4 weeks. For the first 2 weeks, the HA mixture was given at $45 \mathrm{~mL} /$ day (HA content, $225 \mathrm{mg} /$ day) and it was given at $30 \mathrm{~mL} /$ day (HA content, $150 \mathrm{mg} /$ day) for the next 2 weeks. After 2 weeks of intake, knee pain as evaluated using a VAS was significantly improved in the HA group compared to baseline $(p<0.05)$. On the contrary, no improvement in knee pain was recorded in the placebo group. Thus, oral HA can relieve knee pain.

Among all the studies on clinical trials from 2008 to 2015, seven studies involved the treatment of the symptoms associated with synovitis, mainly pain [33-37, 39, 41, 46]; four involved measures taken to relieve synovial effusion or inflammation [38, 43-45]; and three involved measures taken to improve knee muscular strength [42-44].

The studies that used a mixture containing HA and other components could not rule out the possibility that the other components had effects on knee pain. However, studies that used highly pure HA (more than $97 \%$ ) also reported a beneficial effect on knee pain. Thus, oral HA can effectively improve knee pain.

It is apparent that there were slightly more female subjects than males investigated in the above-mentioned clinical studies (mean ratio: males $43 \%$, females $57 \%$ ). However, each study involved the same gender ratio for $\mathrm{HA}$ and placebo groups. In general, the number of female OA patients was larger than the number of males. This is probably because females have lesser muscles than males and therefore, the burden on the knee increases. It has been reported that HA is regulated by ovarian steroids [47]; however, it is not yet clear whether the oral intake of HA influences hormonal balance. This needs further research.

HA intake differs among the respective studies, such as $48-240 \mathrm{mg}$ /day for 2 weeks -12 months. Thus, further research is needed to clarify the minimal effective dose and the minimum intake period of HA.

\section{Safety of HA}

Chicken comb, which contains highly concentrated HA has long been consumed in Germany, France, and China. In Japan, HA dietary supplements have been available since 1992. HA is approved as a healthy raw material of new resource food in China, as a food additive and healthy functional food in Korea, and as a food additive in Japan. In addition, HA is sold globally in countries such as the US, Canada, Italy, and Belgium and no adverse event caused by HA has been reported.

Several safety studies of HA have been conducted (Table 2). No toxicity was observed in single-dose toxicity studies [48-50], repeated-dose toxicity studies [5161], reproductive and developmental toxicity studies [62-69], mutagenicity tests [70-74], and antigenicity studies [75, 76]. It is reported that exogenous HA such us that administered orally is not harmful to human cancer cells [77]. A 12 month clinical study identified no adverse event attributable to HA [41]. Orally administrated 
HA is used by body tissues and approximately $90 \%$ of exogenous HA is metabolized and released in expiration and urine; thus, the polysaccharide does not accumulate at excessive levels in the body [78]. There were no adverse events attributable to HA in any of the aforementioned clinical trials [34-44]. Based on these factors, HA can be considered as a safe food material.

\section{Conclusion}

The population is aging rapidly around the world. In addition to medical treatment, self-medication is more commonly practiced to reduce patient burden and enhance QOL. HA is a safe raw material and the efficacy of oral HA in relieving knee pain was demonstrated in several clinical trials. HA as a dietary supplement exhibits mild efficacy and no side effects. By utilizing these characteristics, HA dietary supplements provide at least some possibility for the treatment and prevention of serious conditions in patients with OA exhibiting mild knee pain. This review may improve the understanding of HA dietary supplements and it is expected that HA will emerge as a modality for treating knee pain that can be safely used by patients.

\section{Abbreviations \\ HA: hyaluronan; IL-10: interleukin-10; JKOM: the Japanese Knee Osteoarthritis Measure; LD50: lethal dose $50 \%$; MW: mean molecular weight; N/A: Not available; NOAEL: No Observed Adverse Effect Level; OA: osteoarthritis; PCT: paracetamol; SF-36v2: the Short Form-36 Acute US Version 2; SOCS3: Suppresor Of Cytokine Signaling3; TLR-4: Toll-Like Recepter 4; WOMAC: The Western Ontario and McMaster Universities Osteoarthritis Index.}

\section{Competing interests}

The authors declare that they have no competing interests.

\section{Authors' contributions}

All authors managed the literature searches, formulated the hypothesis, and contributed to the discussion and conclusions. All authors read and approved the final manuscript.

\section{Author details \\ ${ }^{1}$ R\&D Division, Kewpie Corporation, 2-5-7, Sengawa-cho, Chofu-shi, Tokyo, Japan. ${ }^{2}$ Tokyo Yamate Medical Center, 3-22-1 Hyakunin-cho, Shinjyuku-ku, Tokyo, Japan. ${ }^{3}$ Gate Town Hospital, 1-6-19, Sekimachi-kita, Nerima-ku, Tokyo, Japan. ${ }^{4}$ Shiba Palace Clinic, 1-9-10 Hamamatsucho, Minato-ku, Tokyo, Japan. ${ }^{5}$ SOUKEN Corporation, 1-9-10, Hamamatsu-cho, Minato-ku, Tokyo, Japan. ${ }^{6}$ Department of Life Science, Graduate School of Arts and Sciences, The University of Tokyo, 3-8-1 Komaba, Meguro-ku, Tokyo, Japan.}

Received: 9 November 2015 Accepted: 19 January 2016 BW

\section{References}

1. Centers for disease control and prevention. Prevalence of arthritis-United States, 1997. MMWR Morb Mortal Wkly Rep. 2001;50:334-6.

2. Peyron JG, Balazs EA. Preliminary clinical assessment of Na-hyaluronate injection into human arthritic joints. Pathol Biol. 1974;22:731-6.

3. Nakamura H, Nishioka K. Effects of glucosamine/chondroitin supplement on osteoarthritis: involvement of PGE2 and YKL-40. Jpn J Joint Dis. 2002;1 1: 175-84

4. Dennis $Y$, Wen MD. Intra-articular hyaluronic acid injections for knee osteoarthritis. Am Fam Physician. 2000;62:565-70.

5. Bucci RL, Turpin AA. Will the real hyaluronan please stand up. JAN. 2004;54
6. Fraser JR, Laurent TC, Laurent UB. Hyaluronan: its nature, distribution, functions and turnover. J Intern Med. 1997;242:27-33.

7. Laurent TC, Fraser JR. Hyaluronan. FASEB J. 1992;6:2397-402.

8. Balazs EA, Watson D, Duff IF, Roseman S. Hyaluronic acid in synovial fluid. I. Molecular parameters of hyaluronic acid in normal and arthritic human fluids. Arthritis Rheum. 1967;10:357-76.

9. Seror J, Merkher Y, Kampf N, Collinson L, Day AJ, Maroudas A, et al. Articular cartilage proteoglycans as boundary lubricants: structure and frictional interaction of surface-attached hyaluronan and hyaluronan-aggrecan complexes. Biomacromolecules. 2011;12:3432-43.

10. Bagga H, Burkhardt D, Sambrook P, March L. Longterm effects of intraarticular hyaluronan on synovial fluid in osteoarthritis of the knee. J Rheumatol. 2006;33:946-50.

11. Shimizu C, Kubo T, Hirasawa Y, Coutts RD, Amiel D. Histomorphometric and biochemical effect of various hyaluronans on early osteoarthritis. J Rheumatol. 1998;25:1813-9.

12. Listrat V, Ayral X, Patarnello F, Bonvarlet JP, Simonnet J, Amor B, et al. Arthroscopic evaluation of potential structure modifying activity of hyaluronan (Hyalgan) in osteoarthritis of the knee. Osteoarthritis Cartilage. 1997;5:153-60.

13. Ghosh P, Holbert C, Read R, Armstrong S. Hyaluronic acid (hyaluronan) in experimental osteoarthritis. J Rheumatol Suppl. 1995;43:155-7.

14. Schiavinato A, Lini E, Guidolin D, Pezzoli G, Botti P, Martelli M, et al. Intraarticular sodium hyaluronate injections in the Pond-Nuki experimental model of osteoarthritis in dogs. II. Morphological findings. Clin Orthop Relat Res. 1989;241:286-99.

15. Yoshimi T, Kikuchi T, Obara T, Yamaguchi T, Sakakibara Y, Itoh $H$, et al. Effects of high-molecular-weight sodium hyaluronate on experimental osteoarthrosis induced by the resection of rabbit anterior cruciate ligament. Clin Orthop Relat Res. 1994;298:296-304.

16. Sakakibara Y, Miura T, Iwata H, Kikuchi T, Yamaguchi T, Yoshimi T, et al. Effect of high-molecular-weight sodium hyaluronate on immobilized rabbit knee. Clin Orthop Rel Res. 1994;299:282-92.

17. Fu LL, Maffulli N, Chan KM. Intra-articular hyaluronic acid following knee immobilisation for 6 weeks in rabbits. Clin Rheumatol. 2001;20(2):98-103.

18. Yoshioka M, Shimizu C, Harwood FL, Coutts RD, Amiel D. The effects of hyaluronan during the development of osteoarthritis. Osteoarthritis Cartilage. 1997;5:251-60.

19. Shimizu C, Yoshioka M, Coutts RD, Harwood FL, Kubo T, Hirasawa Y, et al. Long-term effects of hyaluronan on experimental osteoarthritis in the rabbit knee. Osteoarthritis Cartilage. 1998;6:1-9.

20. Wenz W, Breusch SJ, Graf J, Stratmann U. Ultrastructural findings after intraarticular application of hyaluronan in a canine model of arthropathy. $J$ Orthop Res. 2000;18:604-12.

21. Frizziero L, Govoni E, Bacchini P. Intra-articular hyaluronic acid in the treatment of osteoarthritis of the knee: clinical and morphological study. Clin ExpRheumatol. 1998;16:441-9.

22. Pasquali Ronchetti I, Guerra D, Taparelli F, Boraldi F, Bergamini G, Mori G, et al. Morphological analysis of knee synovial membrane biopsies from a randomized controlled clinical study comparing the effects of sodium hyaluronate (Hyalgan) and methylprednisolone acetate (Depomedrol) in osteoarthritis. Rheumatology. 2001;40:158-69.

23. Guidolin DD, Ronchetti IP, Lini E, Guerra D, Frizziero L. Morphological analysis of articular cartilage biopsies from a randomized, clinical study comparing the effects of 500-730 kDa sodium hyaluronate (Hyalgan) and methylprednisolone acetate on primary osteoarthritis of the knee. Osteoarthritis Cartilage. 2001;9:371-81.

24. Maniwa S, Ochi M, Motomura T, Nishikori T, Chen J, Naora H. Effects of hyaluronic acid and basic fibroblast growth factor on motility of chondrocytes and synovial cells in culture. Acta Orthop Scand. 2001;72:299-303.

25. Asari A, Miyauchi S, Matsuzaka S, Ito T, Kominami E, Uchiyama Y. Molecular eight-dependent effects of hyaluronate on the arthritic synovium. Arch Histol Cytol. 1998;61:125-35.

26. Day R, Brooks P, Conaghan PG, Petersen M. A double blind, randomized, multicenter, parallel group study of the effectiveness and tolerance of intraarticular hyaluronan in osteoarthritis of the knee. J Rheumatol. 2004;31:775-82.

27. Santangelo KS, Johnson AL, Ruppert AS, Bertone AL. Effects of hyaluronan treatment on lipopolysaccharide-challenged fibroblast-like synovial cells. Arthritis Res Ther. 2007;9:R1. 
28. Ikeda K. Changes in synovial fluid markers and clinical effects after intraarticular injection of sodium hyaluronate : with particular reference to the anti-inflammatory effect in terms of prostaglandin $E_{2}$ concentration. Tokyo Women's Medical University. 1998;68:22-36 (in Japanese).

29. Hisada N, Satsu H, Mori A, Totsuka M, Kamei J, Nozawa T, et al. LowMolecular-Weight Hyaluronan Permeates through Human Intestinal Caco-2 Cell Monolayers via the Paracellular Pathway. Biosci Biotechnol Biochem. 2008;72:1111-4.

30. Kurihara H, Kawada C, Yoshida H, Kimura M, Kanemitsu T, Masuda Y, et al. Absorption and effect on the skin of oral hyaluronan, $14^{\text {th }}$ Scientific meeting of Japanese society of anti-aging medicine. 2014 (in Japanese).

31. Ishibashi G, Yamagata T, Rikitake S, Takiguchi Y. Digestion and fermentation of hyaluronic acid. Journal for the integrated study of dietary habits. 2002; 13(2):107-11 (in Japanese).

32. Balogh L, Polyak A, Mathe D, Kiraly R, Thuroczy J, Terez M, et al. Absorption, uptake and tissue affinity of high-molecular-weight hyaluronan after oral administration in rats and dogs,". J Agric Food Chem. 2008;56:10582-93.

33. Asari A, Kanemitsu T, Kurihara H. Oral administration of high molecular weight hyaluronan $(900 \mathrm{kDa}$ ) controls immune system via Toll-like receptor 4 in the intestinal epithelium. J Biol Chem. 2010;285:24751-8.

34. Hatayama T, Nagano M, Yamaguchi N, Kumagai S, Ohnuki K. The effect of a supplement on knee pain and discomfort evaluated by visual analogue scale(VAS): a randomized, double-blind, placebo-controlled study. Kenkoshien. 2008;10:13-7 (in Japanese).

35. Kalman DS, Heimer M, Valdeon A, Schwartz H, Sheldon E. Effect of a natural extract of chicken combs with a high content of hyaluronic acid (HyalJoint ${ }^{\circledast}$ ) on pain relief and quality of life in subjects with knee osteoarthritis: a pilot randomized double-blind placebo-controlled trial. Nutr. J.. 2008;7

36. Iwaso H, Sato T. Examination of the efficacy and safety of oral administration of Hyabest ${ }^{\oplus}(J)$-highly-pure hyaluronic acid for knee joint pain. J Jpn Soc Clin Sports Med. 2009;58:566-72 (in Japanese).

37. Sato T, Iwaso H. An Effectiveness study of hyaluronic acid Hyabest ${ }^{\oplus}(J)$ in the treatment of osteoarthritis of the knee on the patients in the United State. J New Rem \& Clin. 2009;58:551-8.

38. Möller I, Martinez-Puig D, Chetrit C. Oral administration of a natural extract rich in hyaluronic acid for the treatment of knee OA with synovitis: a retrospective cohort study. Clin Nutr Suppl. 2009:4:171-2.

39. Nagaoka I, Nabeshima K, Murakami S, Yamamoto T, Watanabe K, Tomonaga $A$, et al. Evaluation of the effects of a supplementary diet containing chicken comb extract on symptoms and cartilage metabolism in patients with knee osteoarthritis. Exp Ther Med. 2010;1:817-27.

40. Yoshimura M, Aoba Y, Watari T, Momomura R, Watanabe K, Tomonaga A, et al. Evaluation of the effect of a chicken comb extract-containing supplement on cartilage and bone metabolism in athletes. Exp Ther Med. 2012:4:577-80.

41. Tashiro T, Seino S, Sato T, Matsuoka R, Masuda Y, Fukui N. Oral administration of polymer hyaluronic acid alleviates symptoms of knee osteoarthritis: a double-blind, placebo-controlled study over a 12-month period. Sci. World J.. 2012;doi:10.1100/2012/167928.

42. Martinez-Puig D, Möller I, Fernández C, Chetrit C. Efficacy of oral administration of yoghurt supplemented with a preparation containing hyaluronic acid (Mobilee ${ }^{T M}$ ) in adults with mild joint discomfort: a randomized, double-blind, placebo controlled intervention study. Mediterr J Nutr Metab. 2013;6:63-8.

43. Moriña $\mathrm{D}$, Solà $\mathrm{R}$, Valls RM, López de Frutos $\mathrm{V}$, Montero $\mathrm{M}$, Giralt $\mathrm{M}$, et al. Efficacy of a Low-fat Yogurt Supplemented with a Rooster Comb Extract on Joint Function in Mild Knee Pain Patients: A Subject-level Meta-analysis. Ann Nutr Metab. 2013;63:1386.

44. Sánchez J, Bonet ML, Keijer J, van Schothorst EM, Mölller I, Chetrit C, et al. Blood cells transcriptomics as source of potential biomarkers of articular health improvement: effects of oral intake of a rooster combs extract rich in hyaluronic acid. Genes Nutr. 2014;9:417.

45. Nelson FR, Zvirbulis RA, Zonca B, Li KW, Turner SM, Pasierb M, et al. The effects of an oral preparation containing hyaluronic acid (Oralvisc ${ }^{\circledR}$ ) on obese knee osteoarthritis patients determined by pain, function, bradykinin, leptin, inflammatory cytokines, and heavy water analyses. Rheumatol Int. 2015;35:43-52

46. Jensen GS, Attridge VL, Lenninger MR, Benson KF. Oral intake of a liquid high-molecular-weight hyaluronan associated with relief of chronic pain and reduced use of pain medication: results of a randomized, placebocontrolled double-blind pilot study. J Med Food. 2015;18:95-101.
47. Raheem KA, Marei WF, Mifsud K, Khalid M, Wathes DC, Fouladi-Nashta AA. Regulation of the hyaluronan system in ovine endometrium by ovarian steroids. Reproduction. 2013;145:491-504.

48. Nagano K, Goto S, Abe Y, Yamaguchi T. Acute toxicity test of sodium hyaluronate. Jpn Pharmacol Ther. 1984;12:37-45 (in Japanese).

49. Wakizawa $Y$, Eiro $H$, Matsumoto $H$, Yamagi M, Yoshihara $K$, Kuramoto $M$, et al. Acute toxicity study of sodium yaluronate(SL-1010) in mice. Jpn Pharmacol Ther. 1991;19:7-12 (in Japanese).

50. Morita H, Kawakami Y, Shimomura K, Sunaga M. Acute toxicity study of sodium yaluronate(SL-1010) in rats and dogs. Jpn Pharmacol Ther. 1991;19: 13-8 (in Japanese).

51. Morita H, Kawakami Y, Suzuki S, Hirata M, Koizumi H. Thirteen-week subcutoneous toxicity study on sodium hyaluronate(SL-1010) with 4-week recovery test in rats. Jpn Pharmacol Ther. 1991;19:19-52 (in Japanese).

52. Morita H, Shimomura K, Suzuki S, Hirata M, Koizumi H. Thirteen-week subcutoneous toxicity study on sodium hyaluronate(SL-1010) with 4-week recovery test in dogs. Jpn Pharmacol Ther. 1991;19:53-80 (in Japanese).

53. Yang G, Zhang T, Guo X, Qu B, Song Y. Toxicological test on calcium hyaluronate. Food and Drug. 2009;11:46-8 (in Chinese).

54. Tan H, Zhao P, Ma Y, Li F, Fu W, He L, et al. Study on toxicology of sodium hyaluronate. Applied Prev Med. 2008;14:296-9 (in Chinese).

55. Guo F, Gao P, Geng G, Wang H, Liu H, Zhi Y, et al. Study on toxicology of sodium hyaluronate. Chinese J Biochem Pharm. 2010;31:316-9 (in Chinese).

56. Oe M, Yoshida T, Kanemitsu T, Matsuoka R, Masuda Y. Repeated 28-day oral toxicological study of hyaluronic acid in rats. Pharmacometrics. 2011:81:1121 (in Japanese).

57. Takahashi J, Seto A, Ishizuka T, Kimura K, Koyama M, Kashiwabara J, et al. Repeated 90-day oral toxicological study of hyaluronic acid in rats. Jpn J Med Pharm Sci. 1985;13:1458-79 (in Japanese).

58. Hasegawa T, Miyoshi K, Nomura A, Nakazawa M. Subacute toxicity test on sodium hyaluronate(SPH) in rats by intraperitoneal Administration for 3 months and recovery test. Pharmacometrics. 1984;28:1021-40 (in Japanese).

59. Kato T, Nakajima S, Kurihara H, Asari A, Sekiguchi T, Sunose A. Preliminary study for the toxicity study on sodium hyaluronate(Na-HA) in rats by repeated oral administration for 13 weeks. The Clinical Report. 1993;27: 5809-30.

60. Ishihara M, Inoue $T$, Ishiyama $Y$, Sakata $T$, Ichikawa A, Funahashi N, et al. Toxicity study on sodium hyaluronate $(\mathrm{Na}-\mathrm{HA})$ in Rats by repeated oral administration for 90 days followed by 28-day recovery study. Pharmacometrics. 1996;51:97-113.

61. Miyoshi K, Hasegawa T, Nakazawa M. Chronic toxicity test on sodium hyaluronate(SPH) in beagle dogs by intra-articular administration for 6 months and recovery test (1) General findings. Pharmacometrics. 1985;29: 49-81 (in Japanese).

62. Ono C, Iwama A, Nakajima Y, Kitsuya A, Nakamura T. Reproductive and developmental toxicity study on sodium hyaluronate(SH)-(1)Study on subcutaneous administration to rats during the period of organogenesis-. Jpn Pharmacol Ther. 1992;20:11-26 (in Japanese).

63. Ono C, Fujiwara Y, Koura S, Tsuchida H, Nakamura T. Reproductive and developmental toxicity study on sodium hyaluronate(SH)-(2)Study on subcutaneous administration to rats prior to and in the early stages of pregnancy-. Jpn Pharmacol Ther. 1992;20:27-35 (in Japanese).

64. Ono C, Ishitobi H, Kuzuoka K, Konagai S, Nakamura T. Reproductive and developmental toxicity study on sodium hyaluronate(SH)-(3)Study on subcutaneous administration to rats during the perinatal and lactation period-. Jpn Pharmacol Ther. 1992;20:37-50 (in Japanese).

65. Guo F, Geng G, Wang H, Liu H, Zhi Y. Teratogenicity test of sodium hyaluronate. Food Drug. 2010;12:321-3 (in Chinese).

66. Tanaka C, Sasa H, Hirama S, Inaba T, Tokunaga S, Eiro H, et al. Reproductive and divelopmental toxicity studies of sodium hyaluronate(SL-1010)(I)Fertility study in rats-. Jpn Pharmacol Ther. 1991;19:81-92 (in Japanese).

67. Tanaka C, Sasa H, Hirama S, Inaba T, Tokunaga S, Eiro H, et al. Reproductive and divelopmental toxicity studies of sodium hyaluronate(SL-1010)(II)Teratogenicity study in rats-. Jpn Pharmacol Ther. 1991;19:93-110 (in Japanese).

68. Wada K, Hashimato Y, Mizutani M, Chiaki T. Reproductive and divelopmenta toxicity studies of sodium hyaluronate(SL-1010)(III)-Teratogenicity study in rabbits-. Jpn Pharmacol Ther. 1991;19:111-9 (in Japanese).

69. Tateda C, Nagaoka S, Nagai T, Nakamura T. Reproductive and developmental toxicity study on sodium hyaluronate(SH)-(4)Study on 
subcutaneous administration to rabbits during the period of organogenesis-. Jpn Pharmacol Ther. 1992;20:51-8 (in Japanese).

70. Sugiyama C, Yagame O. Mutagenicity tests on sodium hyaluronate(SL-1010)(I)Reverse mutation test in bacteria-. Jpn Pharmacol Ther. 1991;19:177-81 (in Japanese).

71. Sugiyama C, Kobayashi H. Mutagenicity tests on sodium hyaluronate(SL-1010)(II)In vitro cytogenetic test-. Jpn Pharmacol Ther. 1991;19:183-91 (in Japanese).

72. Onishi M, Nagata T, Saigou K, Sameshima H, Nagata R. Mutagenicity studies of sodium hyaluronate(SH). Jpn Pharmacol Ther. 1992;20:65-72 (in Japanese).

73. Hara T, Horiya N, Katoh M, Shibuya T. Micronucleus test in mice on sodium hyaluronate(SL-1010). Jpn Pharmacol Ther. 1991;19:193-7 (in Japanese).

74. Aruga F, Miwa Y, Fuzimura T, Ohta S. Micronucleus test of sodium hyaluronate(SH) with mice. Jpn Pharmacol Ther. 1992;20:73-5 (in Japanese).

75. Takemoto M, Ohzone Y, Asahi K. Antigenicity test of sodium hyaluronate(SH). Jpn Pharmacol Ther. 1992;20:59-64 (in Japanese).

76. Kameji R, Itokawa S, Yamawaki C, Tsujita K, Hara Y, Shukunobe K. Antigenicity tests on sodium hyaluronate(SL-1010) in rabbit. Jpn Pharmacol Ther. 1991;19:159-75 (in Japanese).

77. Seino S, Takashita F, Asari A, Masuda Y, Kunou M, Ochiya T. No Influence of exogenous hyaluronan on the behavior of human cancer cells or endothelial cell capillary formation. J Food Sci. 2014;79:1469-75.

78. Oe M, Mitsugi K, Odanaka W. Orally Administered Hyaluronic Acid Migrates into the Skin of Rats. Sci World J. 2014:2014:378024.

\section{Submit your next manuscript to BioMed Central} and we will help you at every step:

- We accept pre-submission inquiries

- Our selector tool helps you to find the most relevant journal

- We provide round the clock customer support

- Convenient online submission

- Thorough peer review

- Inclusion in PubMed and all major indexing services

- Maximum visibility for your research

Submit your manuscript at www.biomedcentral.com/submit 